\title{
РОССИЙСКАЯ ГОСУДАРСТВЕННОСТЬ И ИНТЕГРАЦИОННЫЕ ПРОЦЕССЫ НА ЕВРАЗИЙСКОМ ПРОСТРАНСТВЕ
}

\begin{abstract}
Аннотация. Объявление текущего года Годом российской истории хороший повод для осмысления современных проблем, становления и развития российской государственности, которую всегда отличала идея соборности земель. Россия веками брала под свое крыло различные племена и народы, населявшие бескрайние просторы Евразийского пространства от западных грании до Чукотки и от Северного ледовитого океана до Кушки, сохраняя, при этом, их культурную и языковую самобытность. Считалось правилом, чтобы назначаемые российские начальники знали обычаи и язык населения управляемых ими территорий. Россия, а потом и СССР, вкладывали немалье финансовые, материальные и интеллектуальные ресурсы в сочиально-экономическое развитие присоединяемых территорий.
\end{abstract}

Ключевые слова: политология, международные отношения, идеология, Россия, государственность, интеграиия, постсовесткое пространство, СНГ, политика, экономика.

$\mathrm{H}$ екоторые современные постсоветские политики ставят под сомнение искренность российских намерений при заключении, например, Георгиевского трактата. К сожалению, подобная позиция находит последователей и в других соседних странах, прежде всего - прибалтийских ${ }^{1}$. Отдельные политики даже выдвигают к России, как правопреемнице СССР, материальные претензии, замалчивая, при этом, о громадных вливаниях Советского союза средств в эти территории в послевоенные годы за счет, прежде всего, России. Особенно выпукло эти проблемы высветились в связи с 65-летием Нюрнбергского процесса. Отдельные политические силы в ряде стран дальнего и ближнего зарубежья, да и некоторые с позволенья сказать исследователи в России, пытаются ревизовать решения трибунала, принизить его историческую и политическую значимость. Но, оспаривать решения Нюрнберга - это значит пересматривать итоги второй мировой войны, на которых, в сущности, зиждется весь современный миропорядок. Это не случайно: все в этом мире взаимосвязано. Сегодня важно отделить зерна от плевел и сосредоточиться на путях дальнейшего взаимодействия и интеграции в рамках Содружества Независимых Государств в современных условиях.

Вспомним события конца 1991 года. Как представляется, Советский Союз накопил к этому времени некую критическую массу проблем, которая рано или поздно должна была взорваться. Оценка этому событию дана. Она прозвучала в Послании Федеральному Собранию, с которым выступил Владимир Владимирович Путин в начале своего второго президентского срока. Он охарактеризовал распад СССР,

Barash D. Approaches to Peace: A Reader in Peace Studies / D.P. Barash // Oxford University Press, USA, 2009. как величайшую трагедию двадцатого века. Понимало это, может и не так остро, и высшее политическое руководство страны, находящееся тогда у руля российской власти.

Практически сразу российские политики предпринимают меры, направленные на соборность бывших Советских земель. Создается Содружество Независимых Государств. Не все, что задумывали его создатели, удалось реализовать. В первой половине 90-х годов прошлого века в СНГ было подписано немало документов, отражающих намерения государств сотрудничать на руинах бывшего СССР. Однако в силу недостаточной проработанности этих документов или отсутствия политической воли создателей СНГ большинство договоренностей так и не не было реализовано. Государственной Думой Российской Федерации, например, не были ратифицированы Договор о Зоне свободной торговли, а также Договор о дружбе и сотрудничестве с Грузией, вступление в силу которых могло бы, во многом, изменить сегодняшний ландшафт СНГ. Такова объективная реальность. Но главное получилось. СНГ сыграло неоценимую роль в период распада СССР, предотвратило неконтролируемую эрозию некогда могущественной страны, создало предпосылки для воссоздания новой российской государственности, независимого демократического развития других бывших республик Советского Союза.

Прошли годы. Сегодня СНГ - это форма сотрудничества равноправных независимых государств, признанная международным сообществом региональная межгосударственная организация. Наиболее полно и конкретно совокупность согласованных взглядов государств - участников СНГ, отражающих их общее видение Содружества, цели и задачи его эволюции изложены в Концепции дальнейшего развития СНГ, одо- 


\section{Международные отношения International Relations}

бренной решением Совета глав государств в октябре 2007 года. В соответствии с Концепцией основной целью Содружества является формирование в долгосрочной перспективе интеграционного экономического и политического объединения заинтересованных государств, обеспечивающего эффективное развитие каждого его участника. Наряду с этим в Содружестве реализуются разноуровневые и разноформатные модели взаимодействия, учитывающие специфику национальных интересов и внешнеполитического курса государств - участников СНГ.

Одним из важнейших достижений СНГ за эти годы является сохранение общего гуманитарного пространства. Русский язык, по-прежнему, остается мощнейшей объединительной силой на пространстве Содружества. Этому, во многом способствует политика России и многих других стран Содружества, деятельность различных общественных организаций и, прежде всего, фонда «Русский мир».

Важнейшими событиями в консолидирующей деятельности СНГ на постсоветском пространстве стали принятие Стратегии экономического развития СНГ до 2020 года, которую поддержали все государства участники, празднование 65-ой годовщины Победы в Великой Отечественной войне, утверждение Стратегии международного молодежного сотрудничества на период до 2020 года, а также подготовка ряда перспективных стратегических документов, в частности, новой редакции Договора о зонное свободной торговли, межгосударственной программы «Культурные столицы Содружества» и Межгосударственной программы инновационного сотрудничества. Показательно, что Украина, перманентно дистанцирующаяся от СНГ, проявляет интерес к участию по большинству направлений многостороннего сотрудничества, а Грузия, вышедшая из СНГ по политическим мотивам, продолжает участвовать в ряде экономических соглашений, заключенных в рамках Содружества.

В целом, усилия по правовому и практическому сближению фрагментов постсоветского пространства позволяют рассматривать СНГ не только как организацию, призванную минимизировать последствия переходных процессов 90-х годов прошлого века, но и как стратегический инструмент, обеспечивающий продвижение интеграционных инициатив на основе пошагового согласования действий заинтересованных сторон. При этом, много в этом процессе зависит от реализации идеи соборности российской государственности.

Ключевой задачей по-прежнему остается правовое обеспечение в сфере экономического взаимодействия. Особую значимость приобрела работа над проектом нового Договора о зоне свободной торговли.
Ведь известно, что уже активно реализуется проект Европейского союза «Восточное партнерство», также предполагающий создание зон свободной торговли со всеми европейскими странами Содружества, но уже без России. В этой ситуации Россия взяла инициативу в свои руки и сделала все, чтобы ускорить подготовку нового Договора о ЗСТ. К сожалению, Договор подписали не все государства - участники СНГ. В.В. Путину и И. Каримову даже пришлось подписать специальное коммюнике о присоединении Узбекистана к этому Договору. Российская Федерация первой завершила ратификацию Договора. Теперь российским парламентариям предстоит поработать с партнерами по СНГ, в том числе в рамках Межпарламентской Ассамблеи государств - участников СНГ, чтобы ускорить вступление его в силу.

После приобретения независимости перед странами СНГ встала задача не только сохранить кооперационные связи, но и обеспечить их дальнейшее развитие, только уже на новой рыночной основе. Необходимо было устранить допущенные странами Содружества в первые годы своего становления серьезные ошибки и просчеты, вызванные разрывом этих связей, падением производства и их массовым перепрофилированием, утратой доступа к традиционным источникам сырья, возросшей конкуренцией на мировых рынках теперь уже бывших партнеров по производству.

Выше уже отмечалось, что не все страны одинаково относятся к интеграционным процессам в рамках СНГ, одних сдерживает ориентация на Европейский союз, других внутренне проблемы. Это их выбор. Россия всегда, подчеркивала, что насильно никого никуда загонять не будет. С другой стороны ряд государств и их лидеров придерживаются твердой линии на тесную интеграцию. В ходе проведенного под председательством В.И. Матвиенко «круглого стола» с символическим названием «Большая страна: перспективы интеграционных процессов на постсоветском пространстве в рамках Евразийского союза» подчеркивалось, что большая страна, это не только Россия, это и большая Украина, большой Казахстан, другие страны СНГ. Соборность российской государственности проявляется в этих процессах наиболее ярко.

Одним из первых интеграционных проектов стало создание Союзного государства России и Белоруссии, прошедшее несколько этапов от Сообщества и Союза двух стан, до Союзного государства. Не углубляясь в проблемы и анализ рифов, на которые натолкнулось союзное строительство, следует отметить, что опыт, приобретенный в ходе этого процесса, во многом позволил избежать ошибок и просчетов при реализации других интеграционных проектов на Евразийском пространстве. 


\section{Внешняя политика России / Foreign policy of Russia}

Поистине судьбоносным для России, Белоруссии и Казахстана, да и всего Содружества, стал вопрос о формировании Таможенного союза и Единого экономического пространства.

Известно, что Таможенный союз создавался внутри, а точнее в рамках Евразийского экономического сообщества. И это не случайно. ЕврАзЭС и его предшественники и создавались то именно в целях выхода на таможенный союз. Первым шагом к формированию такого объединения стало подписание в январе 1995 года Соглашения о Таможенном союзе между Российской Федерацией и Республикой Беларусь, к которому затем присоединились Казахстан и Киргизия, а в 1999 году - Таджикистан. И уже в 2000 году был подписан Договор об учреждении Евразийского экономического сообщества. Можно сказать, что договор стал основой для перевода сотрудничества упомянутых стран на качественно новый уровень

Отсюда и разница в принятии решений. В СНГ решения принимаются консенсусом, а в Евразийском экономическом сообществе в соответствии с экономическим весом государства. В Таможенном союзе был создан наднациональный орган - Комиссия таможенного союза, решения которой являлись обязательными для государств - членов ТС.

Вместе с тем, на пути к формированию мощного интеграционного объединения на постсоветском пространстве существовало много препятствий. Это существенные отличия в уровне развития и структуре национальных экономик, расхождения в национальном законодательстве. С учетом того, что в Таможенном кодексе трех стран содержится около 300 отсылочных норм к национальному законодательству, а в Протоколе к нему - 150 поправок к Таможенному кодексу, могут возникнуть проблемы в правоприменительной практике. Значительным тормозом на пути интеграции нередко становятся и политические мотивы, а также попытки различных центров силы оторвать наши страны друг от друга. Жизнь показывает, что дальнейшее промедление с экономической интеграцией приведет к потере инициативы, которую уже готовы перехватить другие. Евросоюз, как уже отмечалось, активизировал свою программу «Восточное партнерство». Китай вкладывает сегодня десятки миллиардов долларов в инфраструктуру стран Средней Азии, а также других стран СНГ. Постепенно наращивают свое присутствие в регионе и Соединенные Штаты Америки, и Турция.

Практика подтвердила, как эти опасения, так и жизненную необходимость Таможенного союза. Все три государства Таможенного союза от участия в этом интеграционном объединении получают весомый прирост экономической активности. Согласно расчетам по интегрированной модели межотраслевого баланса в ближайшие пять лет он оценивается примерно в 15\% внутреннего валового продукта. Этот эффект достигается за счет создания общего рынка товаров, услуг, трудовых ресурсов и капитала. В том числе снижаются издержки, связанные с потерей времени, средств и сил на преодоление торговых и таможенных процедур при пересечении границы.

Государства Таможенного союза вносят вклад в развитие таких важнейших сфер глобального продовольственного рынка, как производство зерна и мяса. Регионы трех стран объединяет огромное количество пахотных земель, самые современные технологии, большое количество специалистов и исторические связи. Казахстан и Россия являются крупными поставщиками зерна, а при условии проведения скоординированной работы смогут стать ключевыми поставщиками на мировом рынке и по другим группам товаров, включая мясо.

Однако, как известно, в 2008 году разразился мировой финансово-экономический кризис. Внешнеторговый оборот России с ее партнерами по ЕврАзЭС сократился на $40 \%$. И, тем не менее, именно на этот кризисный период пришлась самая активная фаза работы по подготовке правовой базы Таможенного союза, которая состоит из более чем 70 документов. Таможенный союз является важным фактором преодоления последствий кризиса не только для «тройки», но и для всего Евразийского сообщества, поскольку позволяет создать большую региональную зону устойчивого развития путем ликвидации таможенно-тарифных барьеров. Более того, как оценивают эксперты «в случае успешного строительства Таможенный союз может стать ядром интеграционных процессов, основой создания регионального объединения в СНГ и экономической консолидации постсоветского пространства».

По данным экономистов, занимавшихся возможными результатами работы Таможенного союза совокупный экономический эффект от его функционирования оценивается в более чем 400 миллиардов долларов. Создается огромный рынок с населением 165 млн. человек, общим товарооборотом в 900 млрд. долларов, производством сельхозпродукции в 112 млрд. долларов. Три государства обладают почти $83 \%$ экономического потенциала бывшего СССР.

Уже сейчас очевиден макроэкономический эффект создания Таможенного союза. В 2012 году товарооборот трех стран с внешним миром превысит 1 трлн.долларов США. Объем взаимной торговли уже превысил 73 млрд. долларов, Причем, наиболее быстро растут объемы приграничной торговли между 


\section{Международные отношения International Relations}

Казахстаном и Россией. Можно было бы привести, к примеру, опыт Курганской области.

Закономерно возникает вопрос о необходимости перехода в Таможенном союзе на единую валюту. О том, что региональная интеграция в СНГ позволит противостоять вызовам глобализации и другим угрозам и, что необходимо перейти на единую валюту, говориться давно и много. Еще в 2002 году Президент Казахстана Н.А.Назарбаев назвал нонсенсом ситуацию, когда расчеты между нашими бизнесменами осуществляются в иностранной валюте.

Вместе с тем, как известно, формирование союза идет не беспроблемно, а иногда и со сбоями. Не вдаваясь в подробности, остановлюсь лишь на некоторых моментах. Жизнеспособность таможенного союза будет зависеть от вовлечения в процесс его становления максимально широкого круга хозяйствующих субъектов и интенсификации хозяйственных связей между Белоруссией и Казахстаном. Несмотря на оптимистические оценки прироста ВВП (4\% в год) и общего эффекта от формирования Таможенного союза следует иметь в виду, что России неизбежно приходится нести крупные расходы и на интеграционную инфраструктуру, и в связи с возможными потерями, которые возникают из-за необходимости решения фискальных вопросов функционирования Таможенного союза. С этим придется считаться нашим соратникам по ТС.

Есть и другие проблемы правового характера. В Таможенном союзе, как известно, предусмотрена единая таможенно-тарифная политика в отношении третьих стран. В связи с этим участникам союза необходимо будет унифицировать с ними свои отношения. У России насчитывалось около 120 базовых торговых договоров с другими странами, у Казахстана - 50, у Белоруссии - 40. И все это надо было откорректировать, ориентируясь на гармонизацию законодательства с ЕС. Таково главное условие формирования Таможенного союза, зафиксированное в его основных документах

Проведена громадная и сложная работа и, все же, лидеры трех стран решительно двигаются вперед. На следующем этапе предполагается сформировать правовую базу Единого экономического пространства трех стран. Для этого требуется ввести в действие еще 17 базовых соглашений плюс целый пакет других документов.

Bсе эти документы предполагают возможность присоединения других государств. Некоторые страны Содружества уже проявляют к этому практический интерес. С созданием Единого экономического пространства трех стран развитие взаимной торговли будет идти еще более ускоренными темпами. Этот масштабный проект открывает дополнительные возможности для экономики государств — членов, повышения их конкурентоспособности, активизации встречного движения капиталов, технологий, товаров. Создание мощного регионального рынка станет реальным фактором роста и развития России, Белоруссии и Казахстана. Совет Федерации принимал самое активное участие в формировании правовой базы ТС и ЕЭП. За неполных три с половиной года было подготовлено и ратифицировано около 100 документов, в том числе Таможенный кодекс трех стран. Это ли не яркий пример проявления соборности российской государственности.

Принципиально важно, что ЕЭП будет базироваться на согласованных действиях в ключевых институциональных областях — в макроэкономике, в обеспечении правил конкуренции, в сфере техрегламентов и сельскохозяйственных субсидий, транспорта, тарифов естественных монополий. А затем - и на единой визовой и миграционной политике, что позволит снять пограничный контроль на внутренних границах. Принято решение начать кодификацию правовой базы Таможенного союза и ЕЭП. Для повседневной работы участникам экономической жизни будет достаточно всего лишь двух базовых документов - Таможенного кодекса и Кодифицированного договора по вопросам Таможенного союза и ЕЭП. В 2012 году в полном формате заработает и Суд ЕврАзЭС. Обращаться в суд по всем фактам, связанным с дискриминацией, нарушением правил конкуренции и равных условий ведения бизнеса, теперь могут не только государства, но и участники экономической деятельности.

Все это позволяет выйти на следующий, более высокий уровень интеграции - к Евразийскому экономическому союзу, который послужит своего рода центром дальнейших интеграционных процессов. Предполагается, что он будет формироваться путем постепенного слияния существующих структур - Таможенного союза и Единого экономического пространства. В перспективе ставится еще более амбициозная задача — создание Евразийского союза.

Предложение о создании Евразийского союза, выдвинутое В.В. Путиным активно поддерживается лидерами стран «тройки». Н.А. Назарбаев напоминает, что еще в 1994 году предложил создать Евразийский Союз Государств, но политики тогда оказались не готовы обсуждать это предложение. По мнению Н.А. Назарбаева, размещение исполнительных органов Евразийского экономического союза в городе Астане избавит новое интеграционное объединение от подозрений в имперских амбициях России, имею- 


\section{Внешняя политика России / Foreign policy of Russia}

щихся как внутри наших стран, так и за пределами нашего объединения. (Сегодня это предложение пока лишь обсуждается, а новый наднациональный орган Евразийская экономическая комиссия уже размещена в Москве) А.Г. Лукашенко подчеркивает, что «Россия впервые за многие годы ясно и недвусмысленно заявила о приоритете отношений с государствами, с которыми, перефразируя классика, вышла из одной общей советской шинели».

Формирование Евразийского экономического союза потребует колоссальных усилий по созданию правовой базы нового объединения, унификации хозяйственного права государств — членов. Опыт работы по созданию правовой баз ТС и ЕЭП подсказывает, что для этого потребуется создавать специальные инструменты, которые занимались бы такой унификацией, вырабатывая Основы законодательства в тех отраслях права, которые будут наиболее востребованы на различных этапах формирования Евразийского союза.

ЕврАзЭС в его нынешнем виде, так и не сумело перейти к принятию Основ законодательства стран - членов, хотя их разработка была предусмотрена Договором о создании Сообщества. Как представляется, Межпарламентская Ассамблея ЕврАзЭС, в составе которой мне довелось работать несколько лет, не смогла справиться с этой задачей в силу отсутствия необходимых у членов МПА необходимых полномочий. Делегирование в Ассамблею представителей парламентов стран — членов не дает им необходимого мандата. Создание Евразийского экономического союза уже на первом этапе потребует наличие полноценного избираемого парламента, подобного Европарламенту.

Не претендуя на истину в последней инстанции, могу предположить, что таким инструментом могла бы стать Евразийская парламентская ассамблея, избираемая населением стран - членов прямым голосованием по единым правилам. Количество «евразийских депутатов» от разных стран может быть различным, при этом следует предусмотреть, чтобы одна страна не доминировала в парламенте. МПА ЕврАзЭС формируется, например, исходя из принципа экономического вклада государства в бюджет объединения. Сейчас Россия имеет в МПА ЕврАзЭС 40 голосов, Белоруссия и Казахстан - по 20, Киргизия и Таджикистан - по 10. По такому же принципу можно было бы избирать и Евразийскую парламентскую ассамблею.

Разработку Основ законодательства следовало бы поручить новому наднациональному органу - Евразийской экономической комиссии, которая занималась бы этой работой совместно с правительствами государств - членов, наряду с выполнением других функций, характерных для исполнительной власти. В этой работе могли бы принимать участие депутаты парламентской ассамблеи, Евразийская торгово-промышленная палата, Евразийский союз промышленников и предпринимателей и другие общественные объединения союза.

Как показывает практика, подготовить и принять Основы законодательства это лишь только начало. Важно добиться, чтобы затем национальные законодательства соответствовали основам в аналогичных отраслях права. Только тогда задача унификации законодательства в рамках союза будет решена.

Одним из инструментов контроля за имплементацией основ союзного законодательства в национальные правовые системы мог бы стать сам союзный парламент, который следует наделить правом ежегодно запрашивать отчеты о ходе этой работы в государствах-членах и проводить по итогам специальные слушания по отчету каждого государства отдельно. Кроме того, следует наделить Суд Евразийского союза правом возбуждать дела о несоответствии законодательства того или иного государства Основам союзного законодательства и вступившим в силу договорам, подписанным в рамках союза по иску государства - члена, а также физического или юридического лица.

В дальнейшем, возможно, потребуется создание специального органа, специализирующегося на унификации законодательства государств — членов союза. В мировой практике есть примеры эффективного влияния на сближение законодательств. Это - деятельность Европейской комиссии за демократию через право, более известной как «Венецианская Комиссия». В расширенное соглашение о комиссии в настоящее время входят около 60-ти государств, в том числе и Россия.

По аналогии с этой практикой можно было бы создать Евразийскую комиссию мониторинга законодательства и сближения правовых систем государств - членов союза. Основной целью такой Комиссии должно стать сближение правовых систем государств - членов союза. С учетом задач, стоящих перед союзом, можно предложить следующие направления работы Комиссии на первом этапе. Это, прежде всего, гражданское право, хозяйственное право (с его многочисленными ответвлениями), уголовное и уголовнопроцессуальное право, административное право, финансовое, экологическое и природно-ресурсное законодательство.. Одной из важнейших задач Комиссии должен стать постоянный мониторинг приведения законодательства государств - членов союза в соответствии со вступившими в силу многосторонними договорами, подписанными в рамках союза и Основами 


\section{Международные отношения International Relations}

законодательства союза в соответствующих отраслях права.

Экспертами Комиссии сроком на 4-5 лет могут назначаться парламентом, Евразийской экономической комиссией и Судом Евразийского союза (в равных долях) известные ученые, специалисты и политики, имеющие опыт юридической работы, судьи конституционных, верховных и арбитражных (хозяйственных) судов, парламентарии из числа граждан государств - членов союза. Для большего авторитета следует предусмотреть в составе экспертов Комиссии минимальную квоту для специалистов из стран ЕС. После одобрения этого предложения в странах союза оно должно приобрести форму международного договора, подлежащего ратификации парламентами государств — членов союза.

$$
* * *
$$

Вышеприведенные суждения, конечно, не исчерпывают всей палитры вопросов, которые пред- стоит решать создателям Евразийского союза. Предстоит долгая и кропотливая работа. Дальнейшее сближение Белоруссии, Казахстана, России, возможно и других стран СНГ - подсказано самой жизнью и является делом весьма перспективным при условии, что политические элиты проявят осознанную готовность к всесторонней интеграции, а главное - к выполнению достигнутых договоренностей.

Но еще более важно то, что за всеми будущими успехами и достижениями стоят судьбы миллионов людей, как в России, так и в СНГ. И можно не сомневаться, что наш общий успех, наша скоординированная деятельность приведет к укреплению российской государственности, дальнейшему развитию демократии во всех странах Содружества, нейтрализации последствий мирового финансового кризиса, вступлению стран СНГ на путь развития экономик на модернизационной основе на благо улучшения жизни людей.

\section{Список литературы:}

1. Barash D. Approaches to Peace: A Reader in Peace Studies / D.P. Barash // Oxford University Press, USA, 2009.

2. Бердяев Н.А. Истоки и смысл Русского коммунизма. М.: «Наука», 1990.

3. Леонтьев К.Н. Византизм и славянство. В кн. Россия глазами русского. М., 1992. 